\title{
PREDICTING PRIVATE SAVING WITHIN MALAY COMMUNITY
}

\author{
Mei Teh Goi ${ }^{1 *}$, Mohd Rizal Palil ${ }^{2}$, Nor Hazila Mohd Zain ${ }^{1}$, and Nor Hasikin Mamat ${ }^{1}$ \\ ${ }^{1}$ Faculty of Business and Accounting, Infrastructure University Kuala Lumpur, \\ Jalan Ikram-Uniten, 43000 Kajang, Selangor, Malaysia \\ ${ }^{2}$ School of Accounting, Faculty of Economics and Management, \\ Universiti Kebangsaan Malaysia, 43600 Bangi, Selangor, Malaysia \\ *Corresponding author: goimt@iukl.edu.my
}

Published online: 20 March 2019

To cite this article: Goi, M.T., Palil, M.R., Mohd Zain, N.H., and Mamat, N.H. (2019). Predicting private saving within Malay community. Asian Academy of Management Journal, 24(Supp. 1), 1-17. https://doi.org/10.21315/aamj2019.24.s1.1

To link to this article: https://doi.org/10.21315/aamj2019.24.s1.1

\begin{abstract}
Few reports have indicated that majority of Malaysians do not save enough for retirement and Malays are less likely to save money as compared to other races in Malaysia. A lot of attention has been given to the link between financial literacy and saving thus neglecting other factors that are closely related to individuals. According to Bandura's (1977) theory, financial behaviour is closely related to personal factors such as individual characteristic, cognitive ability, self-efficacy, and religious faith. Therefore, this study aims to examine all the factors predicting private saving. Using 224 Malay respondents, logistic regression analysis was conducted. This study found that parents and religious faith significantly predicted the likelihood of private saving, but individual characteristic, cognitive ability, and self-efficacy did not significantly predict the likelihood of private saving. Thus, this study recommends using parents and religious officers to guide the Malay communities in their private saving.
\end{abstract}

Keywords: private saving, financial behaviour, cognitive ability, self-efficacy, religious faith

(C) Asian Academy of Management and Penerbit Universiti Sains Malaysia, 2019. This work is licensed under the terms of the Creative Commons Attribution (CC BY) (http://creativecommons. org/licenses/by/4.0/). 


\section{INTRODUCTION}

The increase in average life expectancy and longevity has caused saving behaviour to become more crucial (Curtis, Lugauer, \& Mark, 2017). In Malaysia, low savings rates have become a crucial financial issue. Shagar (2016) reported that many Malaysians suffer insufficient saving during their retirement. As an example, between year 2006 and 2014, the Malaysian household saving rates were averaged at a mere $1.6 \%$ (Kok, 2016). The Malaysian household saving rate in year 2014 was also much lower as compared to China with $37.99 \%$ and the United States with 5.77\% (OECD, 2017). Apparently, both China and the United States have shown a growing trend in their household saving rate. China's household saving rate increased from $30.57 \%$ in 2006 to $37.99 \%$ in 2014, while the United States' household saving rate also increased from $4.72 \%$ in year 2004 to $5.77 \%$ in 2014 . Aiming to be a developed country, however, the saving rate of Malaysian household is considered low as compared to China and the United States. The declining pattern in the saving rate of Malaysians is one of the main future concerns of the policy makers. The Edge Financial Daily reported that in 2014, nearly $88 \%$ of Malaysians had zero earnings in their private savings (Shukry, 2014).

A study in Malaysia indicated that Malays are more likely to have their expenses exceeding their income and they also have a higher tendency to fall prey to credit card debt as compared to other races (Loke, 2014). In addition, Shukry (2014) reported that among the three major ethnic groups in Malaysia, 55\% of Malays have no financial assets which include cash, equity, or deposits securities. Despite being the largest ethnic group in Malaysia, not much has been discovered in terms of the factors influencing private savings within the Malay community. Past studied also confirmed that race is significant in predicting individual financial behaviour (e.g., Garrison \& Gutter, 2010; Hira, Sabri, \& Loibl, 2013; Leon \& Pfeifer, 2017). Apart from that, Keister (2003) indicated that some religious groups are much more likely to have insufficient net worth than others. Leon and Pfeifer (2017) discovered that Muslims are less likely than Christians in taking on financial risk. A number of studies have focused on this phenomenon, however, the emphasis is mainly on the comparison between the Catholics and Protestants. Hence, within Malaysian context, it would be interesting to study the link between religion and financial behaviour among the Malays, who make up the majority group in Malaysia. Additionally, Islamic finance has been one of the most developing financial systems in Malaysia.

Brounen, Koedijk, and Pownall (2016) explained the need to understand why some individuals are good at saving, while others fail. In order to understand personal financial behaviour, two most significant factors have emerged from past literature. 
First, a relationship between household saving and financial literacy has been over established (French \& McKillop, 2016; Jonsson, Soderberg, \& Wilhelmsson, 2017; Mahdzan \& Tabiani, 2013). Second, the literature has moved beyond financial literacy to study the impact of other factors (Abildgren, 2016). Though financial literacy is important, the influence of other factors is not to be undermined (Farrell, Fry, \& Risse, 2016). According to Hondroyiannis (2004), there is a vast literature on the determinants of private saving. Despite, very little attention has been given to household micro-data with detailed household characteristics in past literature (Abildgren, 2016; Ruefenacht, Schlager, Mass, \& Puustinen, 2015). The life-cycle model had been widely used in past literature in understanding private saving (Ruefenacht et al., 2015), however, life-cycle model at times failed to explain aspects of private saving (Brounen et al., 2016; Eriksson \& Hermansson, 2014; Jan \& Lin, 2014; Lown, Kim, Gutter, \& Hunt, 2015). Thus, more theories had been adopted in past literature to understand private saving beyond life-cycle model. Behavioural finance, cognitive psychology, neuroscience, and the unconscious are the new financial decision-making paradigms introduced to solve the failures of the older theories in explaining how individuals make financial decisions (Howard, 2012). Recently, researchers have suggested additional predictor of successful financial behaviour which is self-efficacy (Farrell et al., 2016; Lown et al., 2015). Lown (2011) indicated that Bandura's self-efficacy theory has become widely acknowledged to improve financial behaviour. Yet, there are limited studies linking self-efficacy with financial behaviour (Lown et al., 2015). Relatively little research has focused on other factors that may provide a deeper understanding of basic financial behaviour such as private saving habit. Therefore, this study aims to examine the factors that influence the Malay community on their private saving.

\section{LITERATURE REVIEW}

\section{Theoretical Background}

As household saving is one of the main contributions to gross national saving, it has attracted the attention of policy makers and academic researchers. According to Reinsdorf (2004, p. 17) "saving consists of amounts that are set aside from current income rather than spending on consumption or related purposes". The purpose of saving is to increase the resources available for future consumption (Garner, 2006). Private saving is not only important for future household consumption but also for the nation's long-run economic growth (Garner, 2006). Since lifecycle model has been widely used in understanding private saving (Brounen et al., 2016), pension has always been the centre of discussion, and is linked to private saving (Ang \& Sen, 2011). Additionally, some studies had combined both 
micro-economic and macro-economic factors in private saving (Ang \& Sen, 2011; Hondroyiannis, 2004). However, few studies had suggested that other theories can be adopted in understanding why some individuals save money, while some others do not (Brounen et al., 2016; Furnham \& Goletto-Tankel, 2002). DeBondt, Forbes, Hamalainen, and Muradoglu (2010) explained that behavioural finance can be used to understand how decisions are made. To understand financial behaviour, Howard (2012) mentioned five paradigms employed in past studies namely, (1) rules of thumb, (2) rational being theory, (3) cognitive psychology/behavioural finance, (4) neuroscience, and (5) unconscious. Howard (2012) further explained that a new paradigm of financial behaviour includes the third, fourth, and fifth paradigms. These suggestions match with Bandura's theory. Bandura (1982) explained that efficacy involves a generative capability in which cognitive, social, and behavioural skills components are to be integrated to serve innumerable purposes. Based on the review of past literatures, this study found five theories that were recommended in financial decision-making which are individual characteristics (Gutter \& Copur, 2011; Hullgren \& Soderberg, 2013), self-efficacy (Farrel et al., 2016), cognitive (Boyle et al., 2013; Estelami, 2009; Okonkwo, Wadley, Griffith, Ball, \& Marson, 2006), socialisation (Hira et al., 2013; Shim, Barber, Card, Xiao, \& Serido, 2010; Ruefenacht et al., 2015), and religious faith (Baxomusa \& Jalal, 2014; Keister, 2008).

\section{Individual Characteristics and Saving}

Past literature had examined various types of individual characteristics' dimensions with financial behaviour. Within individual characteristics, age is a factor that has received most attention because life-cycle model has been mostly adopted in past literature (Ang \& Sen 2011; Brounen et al., 2016; Hondroyiannis, 2004). Curtis et al. (2017) found that different age groups showed different patterns in their private saving, in which senior citizens had higher saving rates. Other dimensions of individual characteristics that are linked to financial behaviour are income level (Ang \& Sen 2011; Eriksson \& Hermansson, 2014; Mahdzan \& Tabiani, 2013), education level (Furnham \& Goletto-Tankel, 2002; Hullgren \& Soderberg, 2013), income (Furnham \& Goletto-Tankel, 2002; Gutter \& Copur, 2011; Lown et al., 2015; Mahdzan \& Tabiani, 2013), and gender (Furnham \& Goletto-Tankel, 2002; Mahdzan \& Tabiani, 2013). Past literature had found mixed results on the impact of individual characteristics on financial behaviour, thus further investigation of the individual characteristics is needed. For example, age and gross income are found to be significantly related to private saving (Lown et al., 2015). Lown et al. (2015) explained that individuals with lower income were more likely to save as compared to those with higher income. Additionally, Mahdzan and Tiabiani (2013) also found that gender, age, income, and education are significantly related 
to the probability of having positive saving among Malaysians. However, Brounen et al. (2016) discovered that both gender and age were not significant predictors of willingness to save. Loke (2014) agreed that gender did not significantly influence individual financial behaviour. Furthermore, Lown et al. (2015) also supported that gender and levels of education were not significantly related to private saving.

\section{Socialisation and Saving}

Socialisation refers to the process of acquiring and developing individual financial attributes (Sabri, Cook, \& Gudmunson, 2012). Parents are recognised as an important agent in predicting young adults' financial behaviour (Shim et al., 2010). A study by Hira et al. (2013) found that parents and media significantly influenced an individual's investment regularity, however, peer and workplace did not. Webley and Nyhus (2013) studied economic socialisation, saving, and assets among European young adults and teenagers. The study found varying results among the parents in terms of encouraging saving and future orientation. Therefore, Webley and Nyhus (2013) suggested that financial education needs to be provided in schools. Ruefenacht et al. (2015) applied the theory of structuration which explains the creation of social systems that can influence an individual's long-term private saving. The study showed that family and friends significantly influenced an individual's perceived importance of long-term savings. The same finding was discovered by Brounen et al. (2016) in which family had an influence on an individual's private saving. A study among college students in Malaysia suggested five agents of financial socialisation that include parents, media, peers, school, and religion (Sabri et al., 2012). The study found only parents and religion to be significantly related to financial literacy.

\section{Cognitive Ability and Saving}

To date, numerous studies have focused on the impact of cognitive ability on financial literacy, however, Banks (2010) indicated neglect on the impact of cognitive ability towards financial decision. Oechssler, Roider, and Schmitz (2009) and Estelami (2009) proposed that cognitive ability plays a prominent role in behavioural finance or financial decisions. Johnston, Kassenboehmer, and Shields (2016) confirmed that cognitive ability is significantly related to financial allocation. Some past literature had used multidimensional instruments to measure cognitive ability. For example, in conducting a neuropsychological test, a study by Sherod et al. (2009) employed neuropsychological test battery that has nine dimensions which are widely used in clinical diagnosis of dementia. The study indicated that all dimensions of neuropsychological test were related to financial capacity. However, not all literature concurs with this finding. Johnston et al. 
(2016) and Okonkwo et al. (2006) adopted three dimensions of cognitive ability and found that not all dimensions are related with financial literacy or financial ability. This study adopted a unidimensional test of cognitive ability introduced by Frederick (2005). Frederick (2005) introduced a measurement to solve mathematical questions on which intuitive answers are wrong. Oechssler et al. (2009) had adopted Frederick's (2005) test in predicting behavioural economics and finance. Oechssler et al. (2009) suggested that individual with higher cognitive abilities may save more and hope for higher returns.

\section{Religious Faith and Saving}

Past literature has extensively focused in comparisons among different religious groups on financial behaviour (e.g., Garrison \& Gutter, 2010; Hira et al., 2013; Jamaludin, 2013; Leon \& Pfeifer, 2017; Sabri et al., 2012). There are only few studies which have examined the relationship of religion with financial decision. Keister (2008) had examined the correlations between religious affiliation and wealth ownership and found that religious affiliation was significantly related to wealth ownership. Renneboog and Spaenjers (2012) indicated that religious households are more likely to save as compared to non-religious households. Religiosity has significant effects on a firm's adjustment speeds towards its targeted capital structure (Baxomusa \& Jalal, 2014). All the studies above concurred on the influence of religion on financial behaviour. However, Jamaludin (2013) found no significant influence of religion on individual investment choice decisions among Malaysians.

\section{Self-Efficacy and Saving}

The role of self-efficacy in financial behaviour has created an interest among researchers in adopting Bandura's (1977) theory. Self-efficacy is used to analyse changes in fearful and avoidant behaviours (Bandura, 1977). Bandura (1977, p. 193) explained that "self-efficacy is the conviction that one can successfully execute the behaviour required to produce the outcomes". There is a large body of evidence that self-efficacy influences financial behaviour. For example, using women samples, Farrell et al. (2016) found that women with higher financial self-efficacy were more likely to save money. Lown et al. (2015) reported that self-efficacy was positively related to private saving and individuals with low self-efficacy were more likely to save money as compared to those with high selfefficacy. Dietz, Carrozza, and Ritchey (2003) whose study focused on retirement plans and financial self-efficacy found that self-efficacy was not significantly related to retirement saving plan. 


\section{Model}

Based on the above discussion, a model is suggested. Since individual private saving is divided into two groups, a binary logistic regression model was used to determine the likelihood of an individual to save or otherwise. Binary logistic regression is described as a specialised form of regression that is formulated to predict the likelihood of a binary categorical variable (Hair, Black, Babin, \& Anderson, 2014). The form of the logistic regression equation is:

$$
\ln (p / 1-p)=\beta 0+\beta 1 X 1+\beta 2 X 2+\beta 3 X 3+\beta 4 X 4+\beta 5 X 5+\varepsilon
$$

where $p$ is saving, $X 1$ is individual characteristic, $X 2$ is socialisation, $X 3$ is cognitive ability, $X 4$ is religion faith, and $X 5$ is self-efficacy.

\section{METHODS}

\section{Instrument Development}

The instrument, which consists of four sections, was designed based on review of past literature. The instrument was first written in English and was then translated into Malay by a qualified translator. A pilot test was conducted in which respondents were given the options to either answer in English or Malay. Socialisation was measured using Hira et al.'s (2013) 6 items with 5-point Likert scale. Cognitive ability was measured using 3 items from a study by Frederick's (2005). Oechssler et al. (2009) explained that Frederick's (2005) test is quick and favourably used in observed behaviour. Keister (2008) introduced a measurement of religious faith that consists of 17 items which are divided into 3 dimensions namely divine guidance, accumulation, and sacrificial. Religious faith was measured using a 5-point Likert scale ranging from 1 (strongly disagree) to 5 (strongly agree).

\section{Population and Sample}

The data were collected via a self-administered survey. Hair et al. (2014) suggested that a sample size of 200 or more is recommended in multivariate data analysis for acceptable levels of power. Thus, using convenient sampling technique, questionnaires were distributed to 300 Malay respondents, whose age ranged between 16 to 60 years old. This age group was used since the legal age for employment in Malaysia is between 16 to 60 years old. The non-randomisation of sample selection and the violation of the independence assumption of the general 
linear model for oversampling of specific group were not issues of concern since logistic regression was adopted in this study. A total of 223 Malay respondents were included in the final analysis.

\section{RESULTS}

Table 1 illustrates the descriptive statistics and Cronbach's alpha value for the independent variables which were continuous data. The mean, standard deviation, and skewness of the variables did not violate the basic assumptions of the statistical tests. The Cronbach's alpha value is above 0.60 which is considered as a very minimum acceptable value (Hair et al., 2014).

Table 1

Descriptive statistic for continuous variables

\begin{tabular}{lccccc}
\hline Variables & Items & Mean & SD & Skewness & Cronbach's alpha \\
\hline Socialisation & & & & & \\
$\quad$ Parents & 3 & 2.92 & 0.94 & -0.14 & 0.80 \\
$\quad$ Peer & 1 & 2.73 & 0.90 & -0.05 & - \\
$\quad$ Media & 7 & 2.84 & 0.80 & -0.23 & 0.91 \\
$\quad$ Workplace & 1 & 3.12 & 0.96 & -0.11 & - \\
Divine & 7 & 3.97 & 0.63 & -0.02 & 0.91 \\
Accumulation & 2 & 2.37 & 0.83 & 0.35 & 0.61 \\
Sacrificial giving & 5 & 3.31 & 0.56 & 0.33 & 0.69 \\
Self-efficacy & 6 & 2.83 & 0.74 & 0.02 & 0.82 \\
\hline
\end{tabular}

Based on Table 2, a majority of the respondents (84.55\%) claimed they had private saving and a minority of them (15.45\%) did not have private saving. In terms of cognitive ability, none of the respondents answered all the three items correctly. Therefore, only two categories emerged: the $50.2 \%$ who answered one correctly was categorised as low level and the other $49.8 \%$ who answered two correctly was categorised as intermediate level. Majority of the respondents were female with $69.1 \%$, and $40.8 \%$ of income distributions were between RM2,000 to RM3,999 per month.

A logistic regression analysis was conducted to examine if cognitive ability, socialisation, individual characteristic, religious faith, and self-efficacy predicted one's tendency to save money. Since the data were collected using a non-probability method, logistic regression with bootstrap of 5,000 was performed. When all eight predictors were considered together, they significantly predicted an individual's 
tendency to save money, $\mathrm{X}^{2}=56.61, \mathrm{df}=22, \mathrm{~N}=223, p=0.001$. The Cox \& Snell $\mathrm{R}^{2}$ indicate that approximately $22 \%$ or $38 \%$ of the variance can be predicted from the linear combination of the four independent variables. The Hosmer-Lemeshow test statistic is greater than 0.05 , indicating well-fitting models $\left(X^{2}=14.53\right.$, $\mathrm{df}=8, p=0.07)$.

\section{Individual Characteristic}

For individual characteristic, there was no significant influence of gender, age, education, and income towards private saving $(p>0.05)$. This finding is in line with previous studies by Brounen et al. (2016), Loke (2014), and Lown et al. (2015) which found that gender and education level did not play a significant role in predicting private saving. However, the finding of this study is not consistent with Lown et al.'s (2015) and Brounen et al.'s (2016) that found income as an import factor in predicting private saving. This study also found that education and income were not predictors for private saving; a result that is contradictory to Mahdzan and Tabiani's (2013). The results, however, are not surprising because past literature has also indicated such mixed results. Secondly, religion plays a more important role in predicting financial behaviour within the Malay community (Sabri et al., 2012).

\section{Cognitive Ability}

It is interesting to find that cognitive ability is not a significant predictor of the likelihood of private saving. On one hand, the result is in line with Boyle et al.'s (2013) and on another, is contradictory with the findings of Oechssler et al.'s (2009). The result may vary with past literature because measuring cognitive ability was hampered by the lack of agreement on its dimensions within the literature. For example, Johnston et al. (2016) and Okonkwo et al. (2006) adopted a threedimensional test of cognitive ability and found that not all dimensions significantly predicted financial behaviour. This result is also not consistent with Oechssler et al. (2009) who adopted the same measurement. This may be due to the fact that no respondents in this study managed to score high on cognitive ability category. Oechssler et al. (2009) indicated that individuals with high cognitive ability play a more pronounced role in financial behaviour as compared to those with lower cognitive ability. 


\section{Socialisation}

Pertaining to socialisation, parents significantly predicted an individual's tendency to save money (odds ratio $=8.58, p<0.05$ ), whereas peer, media, and workplace were not significant predictors. The odds ratio indicated that when parents' influence is raised by one unit, the odds ratio is 8.58 times more likely to save money. This finding is consistent with Hira et al. (2013), Shim et al. (2010), and Ruefenacht et al. (2015) which found that parents influenced adults' financial decision. The result, however, does not support Hira et al.'s (2013) finding on the influence of media on financial behaviour. The finding is not surprising because Hira et al.'s (2013) study was focused on investment orientation that required an advanced knowledge in finance.

\section{Religious Faith}

As for religious faith, divine guidance (odds ratio $=6.51$ ) significantly predicted an individual's likelihood to save money. Individuals with divine guidance are 6.51 times more likely to save money. But the negative coefficient for accumulation (odds ratio $=7.06$ ) indicates that individuals who have high accumulation are 0.706 times less likely to save money. This finding is consistent with Baxomusa and Jalal's (2014), and Leon and Pfeifer's (2017) that found religion a significant predictor of financial decision. Though the mean score for sacrificial giving is high $(\mathrm{M}=3.31)$, sacrificial giving is not significantly related to private saving. It implies the likelihood of giving back to God without influencing the saving habit among the Malays. This finding is consistent with Keister's (2008) which found that accumulation will reduce private saving because individuals believe that God owns everything $(\mathrm{B}=-0.82)$ and when Malays seek divine guidance in financial decision, the saving is positive $(\mathrm{B}=1.18)$.

\section{Self-Efficacy}

The result of self-efficacy shows its insignificant role in predicting the likelihood of private saving $(p>0.05)$. The result is not in line with Farrell et al.'s (2016), and Lown et al.'s (2015), but is consistent with Dietz et al.'s (2003). The result is expected, however, since Lown et al. (2015) suggested that when controlling for age and income, the results may vary. By considering religious influence on the Malay community, it is not surprising that self-efficacy was not significantly related with private saving. 
Table 2

Logistic regression results and profile

\begin{tabular}{|c|c|c|c|c|c|c|c|}
\hline \multirow{2}{*}{ Variable } & & \multicolumn{2}{|c|}{ Saving } & \multirow{2}{*}{ B } & \multirow{2}{*}{$\mathrm{SE}$} & \multirow{2}{*}{$\begin{array}{l}\text { Odds } \\
\text { ratio }\end{array}$} & \multirow{2}{*}{$p$-value } \\
\hline & & No & $\overline{\text { Yes }}$ & & & & \\
\hline \multirow[t]{5}{*}{ Socialisation } & & 36 & 187 & & & & \\
\hline & Parents & & & 0.89 & 0.30 & 8.58 & $0.003^{* *}$ \\
\hline & Peer & & & -0.40 & 0.34 & 1.35 & 0.25 \\
\hline & Media & & & -0.12 & 0.36 & 0.11 & 0.74 \\
\hline & Workplace & & & 0.24 & 0.34 & 0.47 & 0.49 \\
\hline \multirow[t]{3}{*}{ Cognitive ability } & Low & 19 & 93 & 0.43 & 0.51 & 0.71 & 0.40 \\
\hline & Intermediate (reference) & 17 & 94 & & & & \\
\hline & High & 0 & 0 & & & & \\
\hline \multirow[t]{2}{*}{ Gender } & Male & 15 & 54 & -0.50 & 0.51 & 0.97 & 0.32 \\
\hline & Female (reference) & 21 & 133 & & & & \\
\hline \multirow[t]{6}{*}{ Age } & $20-25$ & 4 & 18 & 0.60 & 1.36 & 0.19 & 0.36 \\
\hline & $25-30$ & 7 & 40 & 1.23 & 1.17 & 1.09 & 0.66 \\
\hline & $30-35$ & 7 & 44 & 1.76 & 1.12 & 2.46 & 0.30 \\
\hline & $35-40$ & 10 & 40 & 0.37 & 1.05 & 0.13 & 0.12 \\
\hline & $40-45$ & 6 & 30 & -0.14 & 1.06 & 0.02 & 0.72 \\
\hline & Above 45 (reference) & 2 & 15 & & & & 0.89 \\
\hline \multirow[t]{4}{*}{ Education } & Secondary & 2 & 38 & 2.10 & 1.16 & 3.25 & $0.04^{*}$ \\
\hline & Diploma & 16 & 42 & -0.70 & 0.84 & 0.70 & 0.07 \\
\hline & Bachelor & 14 & 53 & -0.89 & 0.81 & 1.21 & 0.40 \\
\hline & Postgraduate (reference) & 4 & 54 & & & & 0.27 \\
\hline \multirow[t]{5}{*}{ Income } & Below RM2,000 & 10 & 42 & -0.50 & 1.16 & 0.19 & 0.44 \\
\hline & RM2,000-RM3,999 & 15 & 76 & 0.03 & 0.94 & 0.01 & 0.67 \\
\hline & RM4,000-RM5,999 & 6 & 38 & 1.23 & 1.04 & 1.40 & 0.98 \\
\hline & RM6,000-RM7,999 & 2 & 18 & 1.09 & 1.20 & 0.83 & 0.24 \\
\hline & Above RM8,000 (reference) & 3 & 13 & & & & 0.36 \\
\hline \multirow[t]{3}{*}{ Faith } & Divine guidance & & & 1.25 & 0.49 & 6.51 & $0.01^{*}$ \\
\hline & Accumulation & & & -0.82 & 0.31 & 7.06 & $0.008^{* *}$ \\
\hline & Sacrificial giving & & & -0.04 & 0.51 & 0.01 & 0.95 \\
\hline Efficacy & & & & 0.37 & 0.31 & 1.39 & 0.24 \\
\hline
\end{tabular}

Note: ${ }^{*} p<0.05 ;{ }^{* *} p<0.01 ; \mathrm{B}=$ unstandardised regression weight; $\mathrm{SE}=$ standard error 


\section{DISCUSSION AND CONCLUSION}

The objective of this study was to examine the factors that influence the Malay community on their private saving. This study found support for parents and religious faith's role in predicting the Malay community on their private saving. This study also found that individual characteristic, cognitive ability, peer, media, workplace, and self-efficacy were not the predictors of private saving among Malay community. Based on the findings of this study, divine guidance as the dimension of religious faith is the strongest component predicting saving behaviour among the Malay community. This presents financial institutions with a strong opportunity to use religious faith in promoting saving behaviour among Malay community.

In further understanding private saving, this study aims to fill the gap of previous studies by examining the predictors of private saving. Framed upon Bandura's Social Cognitive Theory (1982), the findings of the study provide evidence for financial planners and counsellors to understand the important factors that influence an individual's financial decision. Most of the past literature has examined the predictors separately or with different combination of predictors. This study has implications on Bandura's theory with the addition of religious faith factor as an important predictor of financial behaviour. Hence, this study contributes to the existing empirical literature on saving by examining all the predictors which were socialisation, cognitive abilities, individual characteristic, religion faith, and selfefficacy in one study. When all predictors were examined together in predicting private saving, as predicted, the results varied as compared to past literature. Parents and religious faith were significant factors in predicting private saving among Malays in Malaysia.

Instead of a general focus on Malaysian communities, this study extends the research of Loke's (2014) and Shukry's (2014) in understanding the factors that influence the Malay community in particular. This study did not aim to generalise the theory, but rather to identify the solutions specific for the largest ethnic group in Malaysia. This study provides empirical evidence on the claims made by previous studies that members of the three major ethnic groups in Malaysia vary in terms of their financial behaviour. The findings of the study clarified the unique factors that influence Malay communities in terms of their financial behaviour. Additionally, the proposed model advances our understanding on these unique factors which can subsequently influence the saving behaviour among the Malays.

This study discovered that parents are the only significant socialisation predictor towards private saving. Peer, media, and workplace may influence an individual on other types of financial behaviour, but not for private saving. Malays usually 
acquire early financial knowledge at home and are heavily influenced by their parents. Parents will increase the ability of the Malay community to save. Given the important role of parents in shaping private saving within the Malay community, future plans should focus on how parents should transfer their financial knowledge to their children. The awareness on the important role of parents in educating their children on financial behaviour is pertinent. Other socialisation factors such as peer, media, and workplace need to be further investigated within other communities or ethnic groups in Malaysia. In conclusion, financial education is primarily provided by the parents and not by other socialisation factors.

Religious faith plays an important role in the Malay community's financial decision making. They seek God's guidance in their financial decision, however, accumulation has provided negative impact towards private saving. To the financial planning companies and policy makers, apart from providing financial literacy trainings for individuals with financial problem, religious experts should also be trained in financial knowledge and be involved in financial decisions within the Malay community. The result also suggests that Malays value sacrificial giving, and their priority is donating to the mosque rather than saving. The Malays also believe that money belongs to God, therefore, saving money is not really important.

This study suggests that there is much more to be explored on the factors influencing personal saving. Financial literacy may not be the only factor predicting financial behaviour; other factors need to be considered in developing a good saving habit. Understanding how other factors affect financial decisions within the Malay community is an important question for future research. The measurement of cognitive ability varies in past literature thus adopting different measurement tool may provide different results. Future research can consider adopting a different measurement tool that fits Malaysian respondents. As this study focused primarily on the Malay community, future research should investigate the factors that influence saving behaviour within other ethnic groups such as the Chinese and Indians. This may improve the understanding of the unique factors for different communities.

Although this study significantly contributes to the body of knowledge, some limitations need to be acknowledged. First is the issue of homogeneity in the income distributions of the sample. Future research needs to consider the homogeneous distribution of sample in terms of gender, education, age, and income. Second, since the data collected were self-reports, the responses may be subject to social desirability bias. Finally, the results may not contribute to the generalisability of the theory within other cultural contexts, instead, this study contributes to the specific body of knowledge within the Malay community in Malaysia. 


\section{ACKNOWLEDGEMENTS}

The authors would like to thank Universiti Kebangsaan Malaysia for providing the research grant (Dana Cabaran Perdana, UKM, DCP-2017-018-2).

\section{REFERENCES}

Abildgren, K. (2016). Household micro-data, regulation and financial stability: The case of Denmark in the 1950s. Studies in Economics and Finance, 33(2), 320-335. https://doi.org/10.1108/SEF-07-2015-0176

Ang, J.B., \& Sen, K. (2011). Private saving in India and Malaysia compared: The role of financial liberalization and expected pension benefits. Empirical Economics, 41(2), 247-267. https://doi.org/10.1007/s00181-010-0386-3

Bandura, A. (1977). Self-efficacy: Toward a unifying theory of behavioural change. Psychological Review, 84(2), 191-215. https://doi.org/10.1037/0033295X.84.2.191

Bandura, A. (1982). Self-efficacy mechanism in human agency. American Psychologist, 37(2), 122-147. https://doi.org/10.1037/0003-066X.37.2.122

Banks, J. (2010). Cognitive function, financial literacy and financial outcomes at older ages: Introduction. The Economic Journal, 120(548), 357-362.

Baxomusa, M., \& Jalal, A. (2014). Does religion affect capital structure? Research in International Business and Finance, 31(May), 112-131. https://doi.org/10.1016/j. ribaf.2013.09.003

Boyle, P.A., Yu, L., Wilson, R.S., Segawa, E., Buchman, A.S., \& Bennett, D.A. (2013). Cognitive decline impairs financial and health literacy among community-based older persons without dementia. Psychol Aging, 28(3), 614-624. https://doi. org/10.1037/a0033103

Brounen, D., Koedijk, K.G., \& Pownall, R.A.J. (2016). Household financial planning and savings behaviour. Journal of International Money and Finance, 69(December), 95-107. https://doi.org/10.1016/j.jimonfin.2016.06.011

Curtis, C., Lugauer, S., \& Mark, N. (2017). Demographics and aggregate household saving in Japan, China, and India. Journal of Macroeconomics, 51(March), 175-191. https://doi.org/10.1016/j.jmacro.2017.01.002

DeBondt, W., Forbes, W., Hamalainen, P., \& Muradoglu, Y.G. (2010). What can behavioural finance teach us about finance? Qualitative Research in Financial Markets, 2(1), 29-36. https://doi.org/10.1108/17554171011042371

Dietz, B.E., Carrozza, M., \& Ritchey, P.N. (2003). Does financial self-efficacy explain gender differences in retirement saving strategies? Journal of Women \& Aging, 15(4), 83-96. https://doi.org/10.1300/J074v15n04_07

Eriksson, K., \& Hermansson, C. (2014). Searching for new saving behaviour theories: How relationship between banks' customers and advisors affect household saving. International Journal of Bank Marketing, 32(4), 279-299. https://doi.org/ 10.1108/IJBM-03-2014-0040 
Estelami, H. (2009). Cognitive drivers of suboptimal financial decisions: Implications for financial literacy campaigns. Journal of Financial Services Marketing, 13(4), 273-283. https://doi.org/10.1057/fsm.2008.24

Farrell, L., Fry, T.R.L., \& Risse, L. (2016). The significance of financial self-efficacy in explaining women's personal finance behaviour. Journal of Economic Psychology, 54(June), 85-99. https://doi.org/10.1016/j.joep.2015.07.001

Frederick, S. (2005). Cognitive reflection and decision making. Journal of Economic Perspectives, 19(4), 25-42. https://doi.org/10.1257/089533005775196732

French, D., \& McKillop, D. (2016). Financial literacy and over-indebtedness in lowincome households. International Review of Financial Analysis, 48(December), 1-11. https://doi.org/10.1016/j.irfa.2016.08.004

Furnham, A., \& Goletto-Tankel, M.P. (2002). Understanding savings, pensions and life assurance in 16-21-year-olds. Human Relations, 55(5), 603-628. https://doi. org/10.1177/0018726702055005429

Garner, C.A. (2006). Should the decline in the personal saving rate be a cause for concern? Economic Review, 91(2), 5-28.

Garrison, S.T., \& Gutter, M.S. (2010). Gender differences in financial socialization and willingness to take financial risks. Journal of Financial Counselling and Planning, 21(2), 60-72.

Gutter, M., \& Copur, Z. (2011). Financial behaviours and financial well-being of college students: Evidence from a national survey. Journal of Family and Economics Issues, 32(4), 699-714. https://doi.org/10.1007/s10834-011-9255-2

Hair, J.F., Black, W.C., Babin, B.J., \& Anderson, R.E. (2014). Multivariate data analysis (7th ed.). Edinburgh Gate: Pearson.

Hira, T.K., Sabri, M.F., \& Loibl, C. (2013). Financial socialization's impact on investment orientation and household net worth. International Journal of Consumer Studies, 37(1), 29-35. https://doi.org/10.1111/ijcs.12003

Hondroyiannis, G. (2004). Estimating private savings behaviour in Greece. Journal of Economic Studies, 31(5), 457-476. https://doi.org/10.1108/01443580410555555

Howard, J.A. (2012). Behavioral finance: Contributions of cognitive psychology and neuroscience to decision making. Journal of Organizational Psychology, 12(2), $52-70$.

Hullgren, M., \& Soderberg, I. (2013). The relationship between consumer characteristics and mortgage preferences: A case study from Sweden. International Journal of Housing Markets and Analysis, 6(2), 209-230. https://doi.org/10.1108/ IJHMA-01-2012-0004

Jamaludin, N. (2013). Religion and individual investment choice decision: The case of Malaysia. International Journal of Business and Social Science, 4(1), 104-113.

Jan, Y.C., \& Lin, Y.C. (2014). Rate of return would not increase to the extent of annuity saving discount. The Economics and Finance Letters, 1(4), 66-69. https://doi. org/10.18488/journal.29/2014.1.4/29.4.66.69

Johnston, D.W., Kassenboehmer, S.C., \& Shields, M.A. (2016). Financial decision-making in household: Exploring the importance of survey respondent, health, cognitive ability and personality. Journal of Economic Behaviour \& Organization, 132(A), 42-61. https://doi.org/10.1016/j.jebo.2016.09.014 
Jonsson, S., Soderberg, I., Wilhelmsson, M. (2017). An investigation of the impact of financial literacy, risk attitude, and saving motives on the attenuation of mutual fund investors' disposition bias. Managerial Finance, 43(3), 282-298. https://doi. org/10.1108/MF-10-2015-0269

Keister, L.A. (2003). Religion and wealth: The role of religious affiliation and participation in early adult asset accumulation. Social Forces, 82(1), 173-205. https://doi. org/10.1353/sof.2003.0094

Keister, L.A. (2008). Conservative protestants and wealth: How religion perpetuates asset poverty. American Journal of Sociology, 113(5), 1237-1271. https://doi. org/10.1086/525506

Kok, C. (2016). Many Malaysian households at risk of shocks. The Star. Retrieved 14 August 2017 from http://www.thestar.com.my/business/business-news/2016/09/03/ many-malaysian-households-at-risk-of-shocks/

Leon, A.K., \& Pfeifer, C. (2017). Religious activity, risk-taking preferences and financial behaviour: Empirical evidence from German survey data. Journal of Behavioral and Experimental Economics, 69(August), 99-107. https://doi.org/10.1016/j. socec.2017.05.005

Loke, Y.J. (2014). Living beyond one's means: Evidence from Malaysia. International Journal of Social Economics, 43(1), 2-18. https://doi.org/10.1108/IJSE-11-20130248

Lown, J.M. (2011). Development and validation of a financial self-efficacy scale. Journal of Financial Counselling and Planning, 32(2), 54-63.

Lown, J.M., Kim, J., Gutter, M.S., \& Hunt, A.T. (2015). Self-efficacy and saving among middle and low income households. Journal of Family and Economic, 36(4), 491-502. https://doi.org/10.1007/s10834-014-9419-y

Mahdzan, N.S., \& Tabiani, S. (2013). The impact of financial literacy on individual saving: An exploratory study in the Malaysian context. Transformations in Business \& Economics, 12(1), 41-55.

Oechssler, J., Roider, A., \& Schmitz, P. (2009). Cognitive abilities and behavioural biases. Journal of Economic Behavior \& Organization, 72(1), 147-152. https://doi. org/10.1016/j.jebo.2009.04.018

Okonkwo, O.C., Wadley, V.G., Griffith, H.R., Ball, K., \& Marson, D.C. (2006). Cognitive correlates of financial abilities in mild cognitive impairment. Journal Compilation, 54(11), 1745-1750. https://doi.org/10.1111/j.1532-5415.2006.00916.x

OECD (Organisation for Economic Co-operation and Development). (2017). Household savings. Retrieved 23 March 2018 from https://data.oecd.org/hha/householdsavings.htm

Reinsdorf, M.B. (2004). Alternative measures of personal saving. Survey of current Business, 84(9), 17-27.

Renneboog, L., \& Spaenjers, C. (2012). Religion, economic attitudes, and household finance. Oxford Economic Papers, 64(1), 103-127. https://doi.org/10.1093/oep/ gpr025

Ruefenacht, M., Schlager, T., Maas, P., \& Puustinen, P. (2015). Drivers of long-term savings behaviour from the consumers' perspective. International Journal of Bank Marketing, 33(7), 922-943. https://doi.org/10.1108/IJBM-11-2014-0168 
Sabri, M.F., Cook, C.C., \& Gudmunson, C.G. (2012). Financial well-being of Malaysian college students. Asian Education and Development Studies, 1(2), 153-170. https://doi.org/10.1108/20463161211240124

Shagar, L.K. (2016). Malaysians not saving enough for retirement. The Star. Retrieved 14 August 2017 from http://www.thestar.com.my/news/nation/2016/05/04/ malaysians-not-saving-enough-for-retirement/

Sherod, M.G., Griffith H.R., Copeland, J., Belue, K., Krzywanski, S., Samrini, E.Y., Harrell, L.E., Clark, D.G., Brockington, J.C., Powers, R.E., \& Marson, D.C. (2009). Neurocognitive predictors of financial capacity across the dementia spectrum: Normal aging, mild cognitive impairment, and Alzheimer's disease. Journal International Neuropsychological Social, 15(2), 256-267. https://doi. org/10.1017/S1355617709090365

Shim, S., Barber, B.L., Card, N.A., Xiao, J.J., \& Serido, J. (2010). Financial socialization of first-year college students: The roles of parents, work, and education. Journal Youth Adolescence, 39(12), 1457-1470. https://doi.org/10.1007/s10964-0099432-x

Shukry, A. (2014). With zero savings, most Malaysians may face dire straits. Retrieved 20 September 2017 from http://www.theedgemarkets.com/article/zero-savingsmost-m\%E2\%80\%99sians-may-face-dire-straits

Webley, P., \& Nyhus, E.K. (2013). Economic socialization, saving and assets in European young adults. Economics of Education Review, 33(April), 19-30. https://doi. org/10.1016/j.econedurev.2012.09.001 